\title{
Erratum to: A fuzzy TOPSIS framework for selecting fragile states for support facility
}

\author{
Eric Afful-Dadzie - Stephen Nabareseh • \\ Anthony Afful-Dadzie · Zuzana Komínková Oplatková
}

Published online: 16 October 2014

C) Springer Science+Business Media Dordrecht 2014

\section{Erratum to: Qual Quant DOI 10.1007/s11135-014-0062-3}

Unfortunately, the author's funding support was incompletely published in the original article. The complete acknowledgement of funding should read as "This work was supported by Internal Grant Agency (IGA) of Tomas Bata University IGA/FAI/2014/037, IGA/FaME/2014/007 and by the European Regional Development Fund under the project CEBIA-Tech No. CZ.1.05/2.1.00/03.0089."

The online version of the original article can be found under doi:10.1007/s11135-014-0062-3.

E. Afful-Dadzie $(\bowtie) \cdot$ Z. K. Oplatková

Faculty of Applied Informatics, Tomas Bata University in Zlin,

T.G Masaryka 5555, 76001 Zlin, Czech Republic

e-mail: afful@fai.utb.cz

S. Nabareseh

Faculty of Management and Economics, Tomas Bata University in Zlin,

Mostní 5139, 76001 Zlin, Czech Republic

e-mail: nabareseh@fame.utb.cz

A. Afful-Dadzie

University of Ghana Business School, Accra, Ghana

e-mail: atosarsah@gmail.com 